\title{
Ethical and Morality in Accounting Epistemological Approach
}

\author{
Emil Horomnea and Ana-Maria Pașcu
}

Alexandru Ioan Cuza University, Faculty of Economics and Business Administration, Iasi, Romania

\begin{abstract}
The major financial scandals and the financial system crisis, have been linked directly or indirectly, to the idea of scam, false or absence of ethics in accounting. The aim of this study is to make an incursion into the history of ethics and morality in accounting, as well as highlighting the importance of these concepts in the economic life of the company. Moreover, given the importance of ethics and morality in the current environment, it takes an ex-ante analysis followed by an expost analysis, to highlight ethical and efficient connection between the multitude of areas on which acts, as well as to show how these principles have emerged and developed. The failure of complying the moral principles and norms of the contemporary world, led to the idea of chaos and lack of provision in the economic plan. Therefore, our approach on the connection between business, ethics, morality, professionalism and accountability is appropriate. Among the objectives of accounting and morality in business is a serious interdependence. Lack of ethical and moral principles in accounting would create preconditions to achieve some "legal fraud", not necessarily related to creativity, but rather to the weakness of an accounting system without rules and ethical principles, reducing the quality of financial information. The research methodology used in developing the study takes into account qualitative methods. The relevant literature is complemented by a comparative analysis of such critical, inductive and deductive reasoning.
\end{abstract}

Keywords: Accounting as a profession, ethics and morality in accounting, true and fair view, quality of accounting information.

\section{Introduction}

Ethics concerns values, what is good and what is bad, and it is a dimension of human society. It is impossible not to get involved in ethics, since what all we do - or do not do can at any time be the subject of an ethical evaluation. Mankind is in a continuous search for the essence of various rules, being thus connected to the essence of morality. Many consider that a moral behavior implies an aware acceptance of specific constraints or rules that limit both reaching our interests and our search for the collective welfare.

The great ethical traditions, more specifically, Indian, Buddhist, Chinese, Jewish, Islamic, and Christian ethics, show how various cultures have attempted to propagate ethical behavior from one generation to another, as well as to understand ethics from a theoretical perspective. All the ideas and principles arisen from these cultures have contributed to the survival and development of society.

Accounting and certified accountants resort to virtues such as: justice, prudence, probity, and dignity, and the professional deontology of the public accountant is concentrated in the mission statement "Science, Independence, Morality". The correlation between ethical principles and the principles of "the science of accounts" results from the

Copyright (C) 2012 Emil Horomnea and Ana-Maria Pașcu. This is an open access article distributed under the Creative Commons Attribution License unported 3.0, which permits unrestricted use, distribution, and reproduction in any medium, provided that original work is properly cited. Contact author: Ana-Maria Pașcu E-mail: , pascuanamaria26@yahoo.com 
fact that any deliberate alteration of the truth is a falsification of reality, an abdication from the principles of ethics and morality.

\section{Scope and Objectives of the Research}

In the present study, we aim to highlight the connections between ethics and morality in accounting, with the purpose of providing an answer to an extremely common question: How important are ethics and morality in accounting? In order to give an answer to this question, we will attempt an incursion in the history of ethics and morality in accounting, in order to know precisely from where we start and what our current position is. The research methodology used in drawing this study employs qualitative methods. The inventory of specialized literature is completed by a critical comparative analysis as well as by inductive and deductive reasoning.

In other words, because of the importance of ethics and morality in the current economic environment, an ex-ante analysis is required, followed by an ex-post analysis, in order to effectively point out the connection between ethical principles and the multitude of fields upon which they act, as well as in order to detail the way in which these principles have occurred and have continuously developed.

\section{Incursion in the History of Ethics and Morality in Accounting and Business}

Accounting is an essential component of the economic science, having the role to quantify and stress the financial position and the performance of a company, including their changes within a determined period of time. The importance of accounting as a profession, always in accordance with the ethical and moral norms imposed by the accounting deontology, determines the need to associate these notions. From Luca Paciolo until the beginning of the $20^{\text {th }}$ century, the progress of accounting is the result of assiduous work performed by theoreticians and practitioners in the field of accounting. For this reason, the new problems imposed by accounting require meeting the ethical and moral principles.

Detailing the ethical principles was not a vital concern in the Ancient Orient; however, essential value concepts can be noticed in: sentences, codes of law, stories with heroes and myths, as well as in the commercial documents of the time. The oldest texts dating from the beginning of the $2^{\text {nd }}$ millennium $\mathrm{BC}$ mention the fact that the societies located on the Tigris and Euphrates Rivers were organized on bureaucratic bases. In those times, people had to serve the gods in order for the latter to facilitate their existence, an idea expressly mentioned in the Babylonian epical creation Enuma Elish (Speiser E. A., 1958).

The king would rule according to a code supposed to have been revealed to him by the supreme god, but which was a reflection of the ethics and social practices of the time. In the Epic of Ghilgamesh, one of the first monarchs of ancient Sumer, king of Uruk in the $3^{\text {rd }}$ millennium $\mathrm{BC}$, he was presented as a man who "investigated, examined, judged, perceived and ruled justly" (Heidel A., 1949). The ethical principles that gave meaning and purpose to Ghilgamesh's life were not mentioned, but merely suggested. He built the walls of Uruk that protected the people. He restored the temples of Anu, protector god of the city, who brought divine blessing to the people, as well as the temples of Ishtar, goddess of love and fertility, who encouraged amiable relationships and the fecundity of crops, birds, cattle, and families (Singer P., 2006). The ethics resulting from this legend is the well known "labor ethics", the fulfillment of destiny by accomplishing one's responsibilities.

The most famous Mesopotamian code of laws, the Code of Hammurabi of Babylon (2003-1961 BC), includes the oldest text of law referring to justice, morality, and accounting. In the same spirit, over two millennia ago, the famous Roman orator and politician Cicero (106-43 BC) trenchantly approaches the lack of morality of dishonest 
men. From his indictment, there results again the existence of accounting. Completing the list of those who prove the existence of accounting and ethical and moral principles, Benedetto Cotrugli, the "unlucky author" (Horomnea E., 2010) drew a treatise of economic behavior ("Della mercantura e del mercante perfeto"), which includes numerous elements of commercial ethics. Destiny wanted for Cotrugli's work, although written before that of Luca Paciolo (1494) (Murphy S. L., 2009), to be published post mortem (1573 and 1602). For this reason, the Italian is known in the history of accounting under this name.

While ancient methods started to shape up in Mesopotamia, an ethical accent also appeared in Egypt. At the basis of Egyptian ethics lay ma'at, a word meaning justice, balance, norm, order, truth, rightful and correct action, principles established by the gods and guaranteed by the pharaohs. The ethical norms included in ma'at were taught in schools by scribes and bookmen. Stories about ethics can also be found in the Jewish scriptures referring to Sedeq, which means justice or virtue and the path towards the truth.

Advancing on the history line, Kant's ethics became the most influential paradigm that attempted to plead for the universal moral principles formulated without turning back to preferences or to a theological background. Another philosopher, sociologist, and economist, Karl Marx, this time against morality, has an open hostile attitude towards moral speculation and virtues. Marx describes morality, together with religion and law, as forms of ideology. He condemns not only bourgeois ideas on morale, as his target is the morality as a whole. At the same time, he regards morale, law, religion, and other forms of social conscience as fundamentally ideological. Modern moral thinking, in essence, criticizes and meditates, without being limited to traditional moral thinking. It questions the received moral ideas, continuously searching for new ways of thinking on the life of individuals. Marx belongs to a radical tradition of modern thought on morale, an approach that also includes Hegel, Nietzsche, and Freud. We could see that these thinkers make us aware of the ways in which moral life inevitably involves us in irrationality. In Marx's opinion, "the reformist reflection on moral could prove utopian, as it tries to modify the structure of our moral beliefs, preserving its bases at the same time" (Singer P., 1993).

In the first decades of the $20^{\text {th }}$ century, more precisely in 1916, John Dewey, one of the most important exponents of pragmatic philosophy in America, pointed out, in his work "Democracy and Education", that, "in fact, morality is as comprehensive as the actions related to our relationships with the others". Morality, he says, refers to the entire character, and character as a whole is identical to man in all his concrete manifestations and attitudes, and in the end he states that "the moral and social aspects of behavior are, after all, identical" (Singer P., 1993).

Most of the $20^{\text {th }}$ century was characterized by a lack of confidence in morality and ethics, by ethical and moral relativism, by post modernist thinking, which questioned the existence of any moral standards, principles, and values claiming to be universal or, paraphrasing Albert Camus, of any "moral absolutes" and even of morality in the traditional sense of the term.

However, starting with the last decade of the $20^{\text {th }}$ century, ethics comes back to the front stage. Debates on ethical subjects take an unprecedented scope. At the same time, ethics research foundations and centers appear, such as the Foundation for Global Ethics, lead by Hans Kung, or the Center for Global Ethics, in the United States of America, which proliferate ethical and deontological codes. We can notice that, starting with the 1990s, we can speak of a true renaissance of ethics and of the interest for ethical issues. Gilles Lipovetsky stated that "the $20^{\text {th }}$ century will be ethical or will not be at all" 
(Lipovetski G., 1996). The deep crises that mankind faced, religion, global governance, as well as life itself, which applies pressures through the problems it implies, have proven that ethics must be acknowledged and taken into account. Carl F. H. Henry stated that ethics became "an incisive and universal requirement for the survival as species" of mankind.

In the last decades, the application of an ethical perspective in specific problems and practical situations started to develop even more. Business ethics takes on a special position in the field of "applied" ethics. In the same way as ethics in medicine, business ethics consists in the application of certain principles in specific situations, just like ethics in accounting. Unlike medicine ethics, business ethics operates in human activities whose practitioners often do not have a professional status and whose reasons are considered less noble. We cannot say the same about accounting ethics, since it is characterized by a professional status of the accountants: public accountants, expert accountants, even auditors, as well as by the noble purpose of this profession, which is to present the financial position and performance of the analyzed economy or company. The history of ethics in business and accounting originates in ancient and medieval times, when pragmatic thinkers such as Cicero analyzed the issue of the correctness in common commercial transactions. As Samuel Noah Kramer stated, business exist since Sumerians times, when commerce and accounting were practiced on a large scale six thousand years ago (Kramer S. N., 1959).

Nowadays, we can see that most researchers agree that the discussions on ethics and morality are less evident in Europe than in the United States. This has changed during the last two decades, as integrationist phenomena became more present in the European public debates, on the one hand, and on the other, under the pressure of the ever more integrated international phenomena, and the situations that require value and moral evaluations are ever more often present in the media.

\section{Valences of the Concept and Regulation of Ethics in Accounting}

According to the Explanatory Dictionary of the Romanian Language, ethics is the science that deals with the theoretical study of values and human behavior from the perspective of moral principles, as well as the totality of moral behavioral norms. Moral refers to an accepted and practiced behavior in a society, the set of spiritual characteristics. Therefore, ethics is one of the main branches of philosophy, which can be called the science of moral reality, dealing with the research of moral issues.

The concept of ethics was used for the first time by Aristotle, as the name of a philosophical discipline. When we speak of the Greek Ethics, the main benchmarks are, besides the one previously mentioned, Socrates and Plato. If Aristotle considered that achieving wealth and money without labor was degrading, the renowned Romanian historian, literary critic, documentary maker, playwright, encyclopaedist, university professor and academician Nicolae Iorga stated that "our country needs, first and foremost, a duty, which is to work. Work is the most appropriate disinfectant of all moral deficiencies".

Based on a coherent set of principles, norms, and conventions, accounting provides, through the "true and fair view", a performance and legitimacy criterion. Without a doubt, accounting based on real, sincere, complete, and neutral information expresses, to a good extent, the degree of morality of the actors involved in the economic activity: investors, the state, the employees, the unions, the manager, the potential investors, etc. (Horomnea E., 2011).

The connection between morality and accounting (Nöel C., Pesqueux Y., 2007) is also presented by Adam Smith, although his 
opinion seems, at first, less absolute. The theory of moral sentiments has been eclipsed by Kant's contemporary work "Groundwork of the Metaphysics of Morals". Aware of the lack of consistency of the theory of moral sentiments, Smith was drawn, 20 years later, to publish The Wealth of Nations. Smith's project was extended, since his ambition was to become a "Newton of the moral world". To this purpose, he started to work on the moral norms and principles, and in connection to this, he aimed to unite morality and the constitution of society and its economic organization. In this project, Smith includes and develops the idea formulated by Hutcheson on the connection between morality and economy. According to Smith, there is no economic man, on the one hand, and a moral man on the other hand, each of them acting according to his own specific motivations and ends, including antagonistic ones. There is, however, a deep unity between these two levels, which should lead to a unity of the moral and economic analyses. Smith's work invites us to see deep into the psychological analysis of the human nature, which is considered as a requirement for understanding the business world, morality, and economy.

In the same manner, books on the epistemology of economy make references to ethics: [...] The economic science cannot reach strong value judgments without consistently resorting to the field of law, history, philosophy, mathematics, statistics, psychology, and ethics (Pohoaţă I., 2011).

The German economist Sombart stressed the role of accounting in the general economic development, in his renowned work Der Moderne Kapitalismus. Accounting, according to Sombart, is the science that contributed for the first time to the assertion of the scientific organization and leadership spirit, which was for a long time an isolated island in an ocean of empiricism. "The double play" allowed capitalism to perfect its company leadership norms, since the use of accounting helps meeting the two essential conditions on which the quality of the management of the shareholders' equity depends: order and clarity. It is known that precisely "order and clarity increase the company's penchant for saving and earning". We believe that order reflects meeting all the moral principles, and clarity is the necessary and absolutely indispensable condition that the accounting information provided by the accounting professional must comply with.

Through its nature, accounting is tightly connected with ethics, morality, and religion (Horomnea E., 2001). At the same time, the concepts of morality and ethics are related, associated, complementary, and indispensable to contemporary world, considering the interdependencies between the markets, the huge quantity of accounting information found on these markets, as well as the fraudulent maneuvers to which financial-accounting information is subject. If it does not meet the moral principles and norms, contemporary world is subject to chaos.

Therefore, in the current economic context, the role of the professional accountant has crossed the limits of a simple job and represents a guarantee of the correctness of the information made public by the economic entities. Overcoming the desire of each individual to be professionally noticed, the professional accountant must meet the information requirements of the harmonized accounting market, oriented towards the stakeholders. In other words, human nature periodically exhibits an irrational behavior determined by the need to stand out professionally and for instant wealth (or "the irrational exuberance", as Alan Greenspan called it). Such circumstances lead to the creation of a speculative sphere, irrespective of whether we speak here of fraudulent maneuvers that made the big world actors in the field of audit, named, at first, the Big Eight, to then become the Big Six and finally the Big Four, or to simply non-complying with the ethical and moral principles in the professional accountant or auditor's performing their attributions. 
Since accountants manifest as actors on a market where they are confronted with the demand and offer of accounting information, they must know how to sell their merchandise. To this purpose, they must provide an image of the position as well as of the performance of the analyzed company, and at the same time meet the ethical code to the end of the accounting activity. Nowadays, a good professional knows what the Romanian accounting reform means, learns to understand and to apply the International Financial Reporting Standards as well as the International Audit Standards, is aware of the importance and scope of applying professional reasoning, councils the company's management in grounding the accounting policies, complies with the professional ethics code, and is aware of the limitations of his judgments. He must acquire certain knowledge and correctly use professional reasoning. Finally, competence always comes first.

The French thinker Michel Barbá reminds us of a great truth: "on the way to progress and civilization, human society cannot detour the idea of order, discipline, and prediction at an economic level". Therefore, the connection that our study makes between business, ethics, morality, professionalism, and accounting is not at all forced, nor obsolete. Between the objectives of accounting and business morality there are serious interdependencies.

The true and fair view, through its very name, makes us think of the idea of truth and honesty, being tightly connected to the performance criterion of accounting, based on ethical and moral concepts: truth, sincerity, regularity, reality, neutrality, continuity, permanence, etc. Interdisciplinarity is obvious and even absolutely necessary at the level of the accounting body, a fact proven by the attempts to harmonize, normalize, and make the accounting practices and principles converge at a world level.

\section{The Importance of Ethics in Obtaining the Quality of Accounting Information}

In the opinion of Robert H. Montgomery, one of the founders of the Lybrand, Ross Bros. \& Montgomery accounting firm, known today as Pricewaterhouse Coopers, "accountants and accounting exist in order to provide public services; the difference between accounting as a simple job and accounting as a social asset is given by the fact that the latter is responsible for meeting standards beneficial for the public interest, beyond the compensation paid by the customers".

In this context, accounting is concerned with drawing professional ethics and behavior standards. General and specialized culture, achieved through a process of permanent training and education, essentially modifies the accounting profession. Performance in the financial accounting activity is a necessary and indispensable condition for complying with the moral and ethical principles.

It is therefore possible to develop a consensual reflection on accounting and management, starting from philosophy. Kerven (Kerven G. -Y., 1993), in his attempt to underline the importance of the organization and management systems, made the distinction between strategic ethics, understanding the axiology in comparison with Rawls, in connection to a system of values and in the conditions of examining these values, together with the professional deontology that means the set of rules applicable by all the professionals in the field. Since accounting insures the function of justification in economy, for individuals and for organizations, we often tend to forget that accounting rules lie at the basis of the crystallization of the values on which society is grounded.

The Anglo-Saxon world tried to issue, through accounting normalization institutions, such rules of professional ethics. 
These standards include the following characteristics: competence, confidentiality, integrity, and objectivity. There is, however, as Jean Cohen-Scali said, an "ontological impossibility to be objective. Since accounting is a language, a means of communication, it has the role to model the events in order to give them a correct meaning and to communicate this meaning. The excessive strictness that many want to give to the normalization process will lead to moving further away from the objective of true and fair view. Therefore, ethics becomes the only true factor of the quality of financial information.

The increase in flexibility in the application of accounting norms in the Anglo-Saxon world determined the appearance of the "business ethics" current. Anglo-Saxons were also the ones who launched the concept of "true and fair view" as a solution to the conflict between "account assistants" and external users. Controversies did not take long to occur, since accounting reality is a "built reality", as the person who draws the financial statements makes a subjective mark on this construct. On the other hand, the external user has their own individuality, interpreting the "reality" built by the accountant according to their own perception and available knowledge.

In this extremely subjective context, ethics is necessary in order to stop the deeply human tendency to create a more attractive personal image. However, generally speaking, truth cannot be known, both because of the subjectivity of the actors on the accounting stage, and because in the accounting structure not all the factors of the economic environment where the company evolves can be taken into consideration. Accounting reality is limited to a "recordable reality".

In the United States of America, there are many bodies that regulate the ethical principles in accounting, of which we mention: the Institute of Internal Auditors, the National Society of Accountants, and the Institute of Public Accountants. In 1887, The
Association of Public Accountants (AAPA) was formed in America, representing the first step towards the development of ethical, moral, and professional principles in the accounting industry in the United States of America (Darwin C. J., 1964).

In an article published in 2007, the Managerial Auditing Journal determined a top of nine factors that contributed to the ethical failures of the accountants, based on a survey made on 66 members of the International Federation of Accountants. These factors include: personal interest, failure caused by the impossibility to preserve independence and objectivity, inappropriate professional judgment, nonapplication of ethical principles, inability to stand up to threats, lack of competence, lack of organizational support, as well as lack of support from the professional association. The main factor remains personal interest, relevant through the accountant's acting according to their own interest, which implicitly leads to the occurrence and development of the conflict of interests. For example, if an auditor notices, while performing the audit mission, an error concerning an account, the auditor can act by not complying with the ethical and moral principles, if he receives material stimuli (Beverley J., et. al., 2007). This is just an example in breaking moral and ethical principles in accounting, which, unfortunately, is not last, but can be the least.

The degree of compliance with accounting laws differs from one country to another. In Germany, the accounting legislation is regulated by the "tax law", while in Sweden there is the "accounting law", and in Great Britain, the "company law". Therefore, countries have their own bodies that regulate their laws (Gowthorpe C., Blake J., 1998).

The main representative of liberal accounting in Romania is the Body of Expert and Public Accountants of Romania. With over 90 years of activity, it got involved not only in the practical regulation of the financialaccounting activity, but also in constantly 
promoting the ethical side of accounting. Moreover, as member of the International Federation of Accountants (IFAC), it permanently contributes to fulfilling the development and promotion objectives of accounting, coordinated at the world level with harmonized standards. A need of the past as well as of the present, created with the purpose to improve the level of uniformity of professional ethics and to establish behavioral norms for all the public accountants of Romania, the National ethical code of professional accountants, with a compulsory application since January 01, 2007, formulates the fundamental principles that must be applied and met by all the professionals, especially by the members of the Body, in order to achieve the common objectives, in accordance with the International Code of Ethics issued by the IFAC international accounting body.

Moreover, the New National Code of Ethics for Professional Accountants approved by the decision of the High Council of the Body of Expert and Public Accountants of Romania no. 11/216 of March 31, 2011, based on the Decision of the National Conference of public and authorized public accountants no. 10/ 65 of September 2, 2010, is compulsory for all CCECAR members in accomplishing their professional services in Romania, starting with January 1, 2011.

The objectives of accounting, established by the Code of Ethics of Professional Accountants, follow the highest standards of professionalism and performance and meet the demands of public interest. In order to achieve these objectives, professional accountants must comply with the fundamental principles based on: independence, integrity, objectivity, professional competence and goodwill, confidentiality, professional behavior, compliance with the technical and professional norms (The National Code of Ethics for Professional Accountants, 2011).

The professional bodies in various countries (including the Chamber of Financial Auditors in Romania) require their members to participate in ethical courses. Apparently, this proliferation of compulsory training in this field implies a lack of ethics of professional accountants. If such training were not necessary, it would not be requested. On the other hand, of all the other jobs, it seems that accounting is almost the only one that requires its members to follow ethical and professional deontology courses (Cheffers M., Pakaluk M., 2007).

The need and importance of professional and personal ethics and behavior norms resides both in the important role of the free accounting professionals towards the state and society, and in the essential need for quality services, based on knowledge, competence, and conscience, independence in spirit and lack of material interest, morality, probity, dignity, and professional behavior.

The professional behavior of accounting experts and public accountants means that they must perform their activity in compliance with the relevant laws and norms, avoiding any action that may discredit this profession.

Building a conceptual accounting frame is related to the ethical grounds of accounting. Ethics in accounting is the search for a true and fair view, although it does not exist in an absolute sense. Ethics is placed at the border between reality and truth. Accounting interprets reality according to what is supposed to be the truth. For this reason, the inexistence of ethical and moral principles in accounting and audit would create the premises for "legal fraud", which is not necessarily related to creativity, but to the weakness of an accounting system lacking ethical norms and principles, thus diminishing the quality of the financial information.

That is the reason why the users of financialaccounting information and implicitly of accounting services trust their quality because practice has proven in time that the 
provision of these services is made according to a moral frame, based on three fundamental desiderata: Ethics, Quality of service and Continuous professional development. We know and acknowledge the fact that there are also exceptions, but these are isolated events. The main objective of professional bodies is to eliminate such cases, and for this reason they create deontological norms, encourage continuous development, and supervise the members of the accounting profession.

\section{Conclusions and Recommendations}

If we were to refer to the importance of ethics in accounting, without getting too exhaustive in our approach, then we could state that the purpose of their occurrence was to direct economic life. As a result, the Machiavellian statement that "the purpose justifies the means" does not belong to the world of transactions, in moral economic competition. We subscribe to the opinion that the truth that accounting attempts to build as a true and fair view is one of the virtues that ethics, morality, and religion cultivate as a priority (Horomnea E., 2010). In a specific manner, accounting notices, notes, quantifies, processes, and communicates specialized information to a well determined market: internal and external users.

In the discussions on ethics in the economic field, there is a tendency to mistake ethics for the moral aspect of business. Although, in dictionaries, these terms are synonyms, there are, however, some differences. In a simplified perspective, ethics is what is allowed by law. Morality implies the notion of "good" and "bad", it resorts to conscience, which is often more exigent. An argument that supports the application of ethics and morality in the field of accounting is the accounting working as language. Accounting is a language that allows transmitting information. As any language, it can be used to transfer true or false data. Ethics is a field of philosophic reflection. We cannot speak of ethics in accounting without referring to the notions of "truth", "good", and "justice" as economic values, accounting being the representation of the economic environment, without which the market of financial information would be "poor", and the stakeholders would be thus deprived of essential information, true masterpieces of the economic reality.

We state that the compliance with ethical and behavioral norms is, first of all, a moral obligation for each practitioner of a profession. This obligation becomes more present and must trigger more responsibility on the practitioners that perform in a field that may influence the general state of economy, as is the case of accounting professionals.

Under these circumstances, the following question arises: Who is responsible for implementing the ethical and moral principles in performing any activity in the name of the company? The answer to this question is as controversial as it is obvious. From our point of view, the entire staff of the company must be responsible for the correct application of ethical norms, by each individual and by the collective. The three Rs, much discussed in specialized papers, respect, responsibility, and result, are remarkable in supporting businessmen in defining the ethical direction to follow. The first $\mathrm{R}$ in business ethics, respect, must be an attitude applied to people, organizational resources, and to the environment. Respect includes behavioral patterns such as: treating all clients and employees with dignity and cordiality. Responsibility includes the responsibility towards the clients, the colleagues, the company, personal and social responsibility. The third $\mathrm{R}$ - result - means understanding the way in which results are obtained, taking into account the fact that they are as important, if not more important, than result itself.

Therefore, the use of a previously mentioned phrase, "the purpose justifies the results", is an excuse much too often used to explain an emotional response or an action that was not 
performed in the conditions of meeting the ethical and moral principles.

The nature of the activities performed by the accountants underlines the need to attain a high level of ethics in accounting and business. Since the stakeholders ground their decisions on accounting information, and auditors certify this information, it is absolutely necessary to involve moral and ethical principles in accomplishing the auditors' mission. Knowing and applying ethical norms helps accountants and auditors overcome the possible ethical dilemmas occurred during the performance of their professional activity, although applying them does not bring any immediate material advantage, since the accounting information provided in the conditions of applying ethical principles is very useful ( Duska F. R., Duska B. S., 2003).

In order to prevent new financial scandals, we believe that accounting professionals, especially auditors and financial consultants, have the moral duty not only to adopt an ethical behavior, but also to insure that those they advise are aware of their own ethical responsibilities, as well as of the consequences of the decisions made. From here truly results the social involvement and responsibility of the accounting profession.

This is precisely the reason why especially we, the accountants, and implicitly the economists, must not forget the importance of ethical and moral principles, both in everyday life, and mainly in performing our professional activities. Any strain from these principles and rules and considering them, first of all, as written rules unworthy of being taken into account and not principles that guide our whole life, only manages to amplify the so-called "legal fraud", which sooner or later will lead to the amplification of the economic problems at a world level.

\section{Acknowledgements}

This work was partially supported by the European Social Fund in Romania, under the responsibility of the Managing Authority for the Sectorial Operational Programme for Human Resources Development 2007-2013 (grant POSDRU/CPP 107/DMI 1.5/ S/ 78342/ 2010).

\section{References}

Casler, D. J. (1964). The Evolution of CPA Ethics: A Profile of Professionalization, Michigan State University.

Cheffers, M. \& Pakaluk, M. (2007). Understanding Accounting Ethics, 2nd edition, Allen David Press, Sutton, Massachusetts.

Colasse, B. (2009). Encyclopédie de Comptabilité, Contrôle de Gestion et Audit, 2nd edition, Economica, Paris.

Dewey, J. (1972). 'Democraţie şi educaţie,' Editura Didactică şi Pedagogică, București.

Duska, F. R. \& Duska, B. S. (2003). 'Accounting Ethics,' Blackwell Publishing.

Gowthorpe, C. \& Blake, J. (1998). 'Ethical Issues in Accounting,' Published by Routledge, Malden MA.

Heidel, A. (1949). 'The Gilgamesh Epic and the Old Testament,' University of Chicago Press, Chicago.

Horomnea, E. (2001). 'Tratat de contabilitate. Concepte, principii, standarde, aplicaţii, Vol. I,' Sedcom Libris, Iaşi.

Horomnea, E. (2010). 'Dimensiuni ştiinţifice, sociale şi spirituale în contabilitate,' Geneză. Doctrină. Normalizare. Decizii, TipoMoldova, Iaşi.

Ionaşcu, I. (1997). 'Epistemologia contabilităţii,' Economică, Bucureşti.

Jackling, B., Cooper, B. J., Leung, P. \& Dellaportas S. (2007). "Professional Accounting Bodies' Perceptions of Ethical Issues, Causes of Ethical Failure and Ethics Education", Managerial Auditing Journal, 22( 9). 
Kerven, G. Y. (1993). 'La culture réseau,' Eska, Paris.

Kramer, S. N. (1959). History Begins at Sumer, New York, Doubleday.

Lipovetski, G. (1996). 'Amurgul datoriei,' Babel, Bucureşti.

Nicolae, M. \& Nicolae, E. E. (2008). "Valori, mentalităţi şi leadership în România," International Research Conference, Leadershipul schimbării în noua economie românească, available at http:// store.ectap.ro/ suplimente/ simpozion REI_ro.pdf

Nöel, C. \& Pesqueux, Y. (2007). 'Éthique et comptabilité,' in the volume of Bernard Colasse, Encyclopédie de comptabilité, contrôle de gestion et audit, 2nd edition, 761772 .

Reiter, S. (1997). "The Ethics of Care and New Paradigms for Accounting Practice," Accounting, Auditing \& Accountability Journal, 10(3), 299-324, available in Emerald database.

Smith, L. M. (2008). "Luca Pacioli: The Father of Accounting," Texas A\&M University, available at http:/ / aaahq.org/ southwest/ pacioli.htm Revised 2011.

Singer, P. (1993). 'A Companion of Ethics,' First Edition, Blackwell Publishing Ltd., Oxford.

Singer, P. (2006). 'Tratat de etică,' translation coordinated by PhD Univ. Boari Vasile and Mărincean Raluca, Polirom, Iaşi.

Speiser, E. A. (1958). 'The creation epic,' in Ancient Near Eastern Texts Relating to the Old Testament, Pritchard, JB. (coord.), Princeton University Press, New Jersey.

Vogel, D. (1992). 'The globalization of business ethics: why America remains distinctive,' California Management Review, 2(3). 